Article

\title{
Shelley's Unknown Eros: Post-Secular Love in Epipsychidion
}

\author{
Michael Tomko \\ Department of Humanities, Villanova University, Villanova, PA 19085, USA; michael.tomko@villanova.edu; \\ Tel.: +1-610-519-3017
}

Academic Editor: Kevin Hart

Received: 3 June 2016; Accepted: 5 September 2016; Published: 14 September 2016

\begin{abstract}
Whether Percy Bysshe Shelley's Epipsychidion-a Platonic poem on love addressed to the patriarchally imprisoned Theresa Viviani or "Emily" - receives praise or blame has generally been determined by two focal passages: a secular sermon on free love and a planetary allegorical thinly veiling his own imbroglio. This essay re-reads Shelley's 1821 work drawing on two recent arguments: Stuart Curran's Dantean call to take the poem's Florentine narrator seriously as a character, not just as an autobiographical cypher, and Colin Jager's outline of Shelley's move beyond the assumptions of his professed atheism after 1816. Based on the poem's structure and imagery, the paper argues that Epipsychidion critiques the false sense of revolutionary ascent and dualistic escape offered to Emily, who is commodified and erased by the narrator's egocentric, "counterfeit divinization of eros" (Benedict XVI). Turning from this Radical Enlightenment Platonism, the poem momentarily realizes an embodied, hylomorphic romantic union akin to the Christian nuptial mystery of two becoming "one flesh" (Mark 10:8). This ideal, however, collapses back into solipsism when the narrator cannot understand or accept love as a "unity in duality" (Benedict XVI). This paper thus claims Epipsychidion as a post-secular inquiry into the problem of love whose philosophic limits and theological horizons are both surprising and instructive. It also reclaims Shelley as a phenomenological poet who can open up the world to Christian and non-Christian readers, one whose Platonic and Dantean formation lend him an openness to transcendence and one whose countercultural path through life makes him wary of inhumane appropriations of religion.
\end{abstract}

Keywords: Shelley; Percy Bysshe; Epipsychidion; British Romanticism; Christianity; love; Dante; Vita Nuova; Plato; postsecular theory

\section{Introduction}

Studies of the relationship between Christianity and England's most idealistic and intellectual poet, Percy Bysshe Shelley, have been definitive. They have also been contradictory. In one account, Shelley was of the devil's party, while knowing it. Writing from the freethinking heart of what Jonathan Israel has termed the Radical Enlightenment [1], he criticized Milton for unfairly tarnishing the moral character of the first revolutionary, Satan, and faced rustification from Oxford for his unapologetic pamphlet The Necessity of Atheism, which challenged the faith of England's religious establishment with William Godwin's high-minded rationality ([2], pp. 206-7; [3]). Within romantic studies, Shelley's antipathy for what he mocked to Benjamin Robert Haydon as "that detestable religion, the Christian," imbrues Stuart Curran's classic study Shelley's Cenci: Scorpions Ringed with Fire (1970) ([4], p. 361; [5]). ${ }^{1}$ The anti-Christian Shelley speaks throughout much subsequent scholarship

1 See Curran's affirmation that The Cenci "constituted a frontal assault on the basis of Christian dogma" ([5], p. 10). 
in methodological approaches ranging from the psychoanalytic to the new historical: Jerrod Hogle's Shelley's Process (1988) traces Shelley's lucid awareness of transferred or projected drives as not only proto-Freudian about humanity's ideals but also proto-Nietzschean about its gods ${ }^{2}$ and, in its recovery of the underground world and intellectual lineage of romantic doubt and defiance, Martin Priestman's Romantic Atheism (1999) makes Shelley its central figure, a kind of poet laureate for disbelief, a role he played for Bertrand Russell at a personal level [6-8]. Shelley's infamous profession of himself as an "atheist" is also inscribed in the literary record ([4], p. 342; [9], pp. 235-38). In James Joyce's representation of Irish cultural wars, Portrait of the Artist as a Young Man (1916) may stage a schoolyard brawl in defense of the scandalous Byron against the institutional Tennyson, but Shelley, not John Henry Newman, ultimately emerges as Stephen Dedalus's real muse, a kind of fallen guardian angel, who liberates the imagination of Joyce's fictional alter ego and fires his seraphic love poetry [10].

There is, however, a Christian view of the radical poet. Defending Shelley against "popular prejudices" and shielding him from T.S. Eliot's and F.R. Leavis's moral, religious, and aesthetic scrutiny, C.S. Lewis finds in him "architectonic power" and "decorum" indebted to Dante and Plato ([11], p. 331). The philosopher of religion Louis Dupré argues that Shelley attains a "spiritual transparency" and "laid the foundations for a natural religion" as part of the overall romantic quest for the absolute, "a relentless and obviously impossible drive to overcome the finitude of the human condition" ([12], pp. 4, 45, 53). More concretely, as part of a study of "romantic religious politics," Robert Ryan's Romantic Reformation (1997) characterizes Shelley's "theological dispositions" as "always subtler than his polemic stances," garnering him a reputation across generations as a "profound religious poet" ([13], p. 193), a categorization used and even amplified by Curran in his other classic study, Shelley's Annus Mirabilis (1975) [14]. ${ }^{3}$ No one exemplifies this veneration more than the mystical vagabond and poet Francis Thompson, whose most important essay summons Shelley's spirit into the Catholic church's cultural life [15]. Any devotees would concede, however, that the romantic poet falls well short of St. Paul's exhortation to preach "Christ crucified" (1 Cor. 1:23 [KJV]). Yet while Shelley, as the author of the essay "On Christianity" [16], is hostile toward all forms of institutional religion, his own admiration of Jesus is virtually unreserved and his theological horizon surprisingly expansive, particularly on the topic of love, which, in the words of St. John the Evangelist, "is of God...for God is love" (1 John 4:7-8). Thus when Coventry Patmore, poet of the theological epithalamium The Unknown Eros (1868-1886), cites Plato's Symposium, he draws on Shelley's translation [17], ${ }^{4}$ even as he denounces writings such as Epipsychidion as nineteenth-century literature's "most powerful moral solvent" ([19], p. 113). Further, the guiding mantra concerning alter egos in the Dantean modern novel, Descent into Hell (1937) by Charles Williams-hieratic Christian writer, theologian of romance, and friend of Eliot and Lewis—comes from Shelley's Prometheus Unbound ([20], p. 19). ${ }^{5}$

Do these two readings-adamantly secular and resolutely spiritual-represent an impasse between two interpretive communities incapable of dialogue? In his philosophic exchange with the theologian Joseph Ratzinger (later Pope Benedict XVI) in The Dialectics of Secularization: On Reason and Religion (2005), Jürgen Habermas describes an ostensibly unbridgeable "generic distinction" in social philosophy between "secular discourse that claims to be accessible to all men and the religious

2 See, for example, the summary of Shelley's theological assumptions in Hogle's reading of the revision of Dante and Plato in Epipsychidion: "He objects, as we know, to any notion of love stemming only from a self-sufficient Father or even from a raised-up daemon or goddess calling the seeker up the steps of knowledge to a monolithic Supremacy beyond all interplay" ([6], pp. 279-80).

3 Curran ranks Shelley as "the greatest religious poet in the English language between Blake and Yeats" and concludes that, though lacking "piety," Shelley's "depth of vision and solemnity of purpose are reminiscent of the great religious poets of western culture" ([14], p. 205).

4 As J.C. Reid points out, Patmore quotes the following in the fourth, 1866 edition of The Angel in the House: "Is it not strange that there are innumerable hymns and poems composed for other Gods, but not one of the many poets who spring up in the world has ever composed a verse in honour of Love, who is such and so great a God?" ([18], p. 41).

5 Williams cites the following from Prometheus Unbound: "The Magus Zoroaster, my dead child, /Met his own image walking in the garden" ([2], 11. I.191, 192). Subsequent citations of Prometheus Unbound will be given in the text parenthetically. 
discourse that is dependent upon the truths of revelation" ([21], p. 42). These polarized interpretations of Shelley seem to exemplify such a split in the sphere of literary criticism. Colin Jager's Unquiet Things: Secularization in the Romantic Age (2015) returns, however, to Shelley as one who can "deterriorialize" such social and intellectual models dependent on "an a priori distinction between religious and secular, private and public" and on "models of public discourse installed by secular arrangements of power and left in place by contemporary religious revivalism" ([9], p. 29). Why Shelley? First, Jager argues, that he, like the romantics in general, lived and moved and had his being in a time when Habermas's "generic distinction" remained sufficiently "unsettled" so that alternative or shared meditations on "human diversity and human flourishing" were possible ([9], p. 30). Second, Jager argues that Shelley himself became aware of his own complicity in the constricting and counterproductive antagonism between the secular disbelief of the Radical Enlightenment and the stagnant confessionalism of England's Establishment. Building on an 1815-16 "turn away from" Godwinian thought that has been frequently recognized by Shelley scholars, Jager argues that the revision of Shelley's relationship to the Radical Enlightenment has "not been taken far enough" ([9], p. 242). Rather, he sees the maturing Shelley as anticipating Charles Taylor's insight that modernity reduces religion to consent to or dissent from propositions that are cognitive and epistemic. This combative reduction occludes any form of potentially ecumenical humanism that thinks about "practices of the self, of governance, of social collectives, and of aesthetics" ([9], p. 22). In dense readings of "Mt. Blanc" and Revolt of Islam, Jager sees Shelley as exploring the possibilities of a more open "countermodernity," one in which increased "sensory capacities" help move the mind from "anger and hatred and revenge" to "other occupations-love, trust, hope, and endurance" ([9], pp. 19, 240). In this view, the later poetry of Shelley, a Shelley "after atheism," begins to think and feel its way past fraught dualisms to explore ontological questions-“"What would an alternative sensorium look like? What kinds of experiences would differently organized bodies have?" ([9], pp. 229, 241). This genuinely interrogative mode is accessible to both secular and religious readers who take seriously such fundamental questions about what the Jewish philosopher, activist, and poet Abraham J. Heschel terms "being human" ([22], pp. 15-17). It also prepares the ground for re-reading Shelley as a phenomenological poet who can re-approach the world with Christian and non-Christian readers, a poet whose Platonic and Dantean formation open him to transcendence and whose oppositional stance braces him against any inhumane, powermongering appropriations of religion.

\section{Epipsychidion after Atheism}

This essay's proposal to extend Jager's reading of late Shelley to the ethereal 1821 poem Epipsychidion may nevertheless seem unpropitious. Although the poem's 605 lines focus on love, its committed dogmatism about free love, with lines 149-173 sometimes excerpted as "sermons" against marriage, recall his youthful commitment to the Radical Enlightenment. ${ }^{6}$ Mary Shelley described the poem as his venture into "Italian Platonics," which was the subject of a series of letters exchanged with Teresa Viviani ([4], p. 636). Known as "Emilia" or "Emily" to the Shelley circle, this intelligent and articulate nineteen-year old from Pisa's gentry had been placed by her family in a convent prior to an arranged marriage. Shelley's philosophical love poem, whose slippery Greek title may roughly translate as a "song of the soul" ([24], pp. 418-19), focuses on Emily and her predicament. More controversially, it is also addressed to her, revisiting, according to its preface, the form of Dante's Vita Nuova. Love, in this case at least, does provoke. Many have speculated on, if not decried, the poem's effects on the long-suffering and loyal Mary Shelley ([25], p. 143; [4], p. 636; [26], p. 346), particularly in its unflattering allegorical deposition of her as a "cold chaste" moon with "pale and

6 The "sermons" can be heard, for instance, in the anthologized Naxos audio recording of romantic poetry [23]. 
waning lips" [27]. ${ }^{7}$ In the wake of the biographical decoding of relationships among the poem's allegorical planets in Kenneth Neill Cameron's "Planet-Tempest Passage in Epipsychidion" [28], Lewis felt the need to sideline such "popular prejudices" to reconsider Shelley's poetry itself ([11], p. 331). For Dupré, however, Shelley's ice "dissolving" (1. 334) ardour for Viviani remains a stumbling block and ultimately leads to his rejection of Robert Browning's claim that the "selfish" and "inflammable poet" was on the road to Christianity ([12], pp. 43, 54). ${ }^{8}$ Feminist criticism has gone further, indicting formal chauvinism that tarnishes the poem's professedly pure admiration for Emily as an "Incarnation of the Sun" (1. 335). From this vantage, apart from any injustice done to Mary, Shelley's egotistical love consistently overshadows the beloved, eclipsing Emily's very personhood ([29], pp. 123-24; [30], pp. 189-93; [31], pp. 141-45). This critique identifies not just Shelley's personal failure but also his symptomatic elimination of the other in a mode of writing, thinking, and loving that never reaches beyond the self. Using the horizon opened by Jager's argument, I will intervene at this point, not to dismiss either the moral or sexual difficulties presented by Epipsychidion or Shelley's behavior, but rather to suggest that the work is what Michael O'Neill has called "self-conscious" [32], and that, as such, the poem's form confronts and begins to work through these questions.

It thus moves into a territory that critics have begun to call the post-secular. This theoretical discourse is developing and contentious, so here I reference only its most basic sense of a considered movement into alternative modes of thought that are, in the words of Lori Branch, "not limited by the secularization thesis or materialist assumptions about literature, persons, and human flourishing" ([33], p. 251). ${ }^{9}$ To trace how Shelley's poem proceeds to just such a position, where the limits of a form of secularism are reached without giving way either to requiring faith or spouting doubt, I will argue that the opening section of Epipsychidion approximates the critique in Deus Caritas Est—Benedict XVI's own philosophic dialogue with Nietzsche on eros and "being human"—of a self-centered love that derives from a problematic version of Platonism [35]. Further, the poem then moves toward envisioning a loving relationship that allows for reciprocity and sustained desire for the other, united in one flesh and embodied in one place. However, because Epipsychidion ultimately lacks, or distrusts, a metaphysics of "two becoming one," the final section cannot rest there and slides back into a domineering egotistical form of love, even though this mode of loving has already been philosophically critiqued. In my reading of the poem's structure, Epipsychidion emerges as a less dogmatic but also less neurotic poem, as a poem whose deepest insights may derive from its closing aporia; as Shelley begins but does not complete the type of phenomenological inquiry into the nature of love undertaken by Jean-luc Marion in The Erotic Phenomenon [36]. Shelley too comes into focus as a flawed but fruitful inquirer, neither ineffectual angel nor licentious beast, whose questioning search may not be conclusive, but who may be worth following across ideological and religious divides.

\section{3. “Tu Autem Non Sic": Questioning Radical Platonism (Lines 1-407)}

This section will argue that the first movement of Epipsychidion, which I will designate as lines 1-407, interrogates Radical Enlightenment Platonism, specifically its antagonistic dualism between body and soul as well as the type of liberation narrative that informs the plots of much Radical Enlightenment literature. The term "Radical Enlightenment Platonism," which uneasily yokes Plato to skeptical philosophes and anti-hierarchical political revolutionaries, may at first seem a misnomer.

7 See lines 281 and 309. Further references to Epipsychidion will be given parenthetically in the text according to line number. Lest the emphasis in Mary's representation be missed, Shelley repeats the adjectives in his description of their "chaste cold bed" (1. 299).

8 Dupré draws on, and ultimately mirrors, the clear-eyed assessment of Hoxie Neale Fairchild who regards Shelley as "the climactic figure in any study of the religious aspect of English romanticism," but delineates him as "a warmly religious but avowedly non-Christian artist," with Epipsychidion far removed "from the gospel of love as taught by Jesus" ([26], pp. 328-29, 341).

9 Additionally, see Branch's "Postsecular Studies" [34] for the best survey of the postsecularism's genealogy and the current state of this interdisciplinary field. For reservations about the term, see Jager ([9], pp. 135-72). 
In Israel's massive, tri-partite intellectual history, Plato generally appears as a counter-Enlightenment philosophical stay against the arguments of the philosophes and as the classical counterbalance to its materialist hero, Spinoza. Yet Israel also hones in on how, particularly in Italian circles, a "highly fraught and bitterly contentious Plato" emerged and fostered, both in Radical Enlightenment writers and their opponents, an "effective proximity of Platonism and Spinozism" ([37], p. 539). While Plato has long been acknowledged as a major influence on Shelley, from the work of James Notopoulos to that of William Ulmer [38,39], the full ideological scope of contemporary neo-Platonists such as Thomas Taylor, with his "suggestive shadows of...pagan phantasms" ([38], p. 54), has only recently come into focus. Attending to philosophic accuracy rather than to the political and social resonances of European Platonic discourses, Notopoulos labels Taylor "the glass through which...Shelley saw Plato darkly" ([38], pp. 53-54). Yet as Priestman's Romantic Atheism has recounted, the prolific Taylor, an anti-Christian translator of Plato and the Greeks, sharpened Plato's subversive edge in England ([7], pp. 96-99, 146). These translations influenced Shelley, Radical Platonism's most infamous spokesperson in England, and provided a cosmic scope to the liberation plot found among English Jacobin writers sympathetic to the French Revolution. In Gary Kelly's study of such storylines in The English Jacobin Novel (1975), he has described the ubiquitous influence of Samuel Richardson's Clarissa (1748), with its narrative of an oppressed victim like Emily suffering unjust captivity. Kelly describes how "the conspiracy of arranged marriage" in the Jacobin novel is then "overthrown, not by rebellion, but by stoic endurance and virtuous candour." Liberation could come not just morally, but metaphysically. According to Kelly, Taylor's version of "Platonic love" provided Godwin with "the English Jacobin version of the redemption of the soul" — an overcoming of patriarchal abuse through radical neo-Platonic redress that corresponds to Emily's plight and flight in Epipsychidion ([40], pp. 17, 41, 141).

In the opening section of Epipsychidion, a "Radical Platonism"- -akin to that of Godwin and Taylor-enables just such a jail break. The cloistered Viviani, whose own writing on Platonic love provides the epigraph, is figured as a caged bird by the poet, who is himself figured in the Advertisement as a dead Utopian dreamer from Florence. At first glance, the poem's defining problem would seem to be political and social, as the poet extravagantly mourns his "adored Nightingale" imprisoned by malicious, regressive patriarchs (1. 10). Shelley, however, resolves this confinement in lines 388-407, at the end of this opening section and just beyond the mid-way point of the poem, when he declares that the "destined Star has risen/Which shall descend upon a vacant prison" $(11.394,395)$. Not only recalling the Bastille, the liberation also sounds with an echoing sense of prophecy arrived- "The day is come"; "The hour is come" $(11.388,394)$-that itself echoes the trumpeting peals of cosmic revolution in Prometheus Unbound_- "This is the season, this the day, the hour" (1. II.i.13). Just as Shelley's grittier, more compact sonnet "England in 1819" concludes by imagining a long-suffering "Phantom" that can "Burst" from the "graves" of England's ills ([41], 11. 13, 14), this emancipation features a spirit that can likewise "burst his charnel" (1. 405). In Epipsychidion, however, spiritualized "true love" (1. 397)—or Il vero amore in Viviani's Italian-catalyzes revolutionary release.

Also in this section comes the infamous "planet-tempest passage" (11. 267-383) as the narrator provides a Platonic spiritual autobiography that begins before birth, seems to trace multiple disappointed loves, and concludes with a recognition of Emily as the long-sought, and now liberated, soul-mate. My argument is that Shelley examines and questions, in this section, the Radical Platonism of the lyrical voice, whom I will refer to as the "Florentine." This is an autobiographically inflected character whose function is not primarily expressive or confessional, but rather emblematic of a philosophic position. Such an approach is similar to Alastor (1816) in which the main character is reflective and critical both of Shelley's own past self and of Wordsworth [42]. This reading accords with Stuart Curran's "Epipsychidion, Dante, and the Renewable Life" that redirects the "wholly dominant reading" away from Cameron's biographical exposé that has made Epipsychidion the "most perversely misread poem in Shelley's canon" ([43], p. 96). Curran forcefully argues that dismissing the prefatory description of the deceased Florentine friend as Shelley's own flimsy cover story has "overdetermined" 
reading the lines as Shelley's "confessional ramblings" or, as in the words of biographer Richard Holmes, Shelley's "most nakedly autobiographical poem" ([43], p. 96; [4], p. 631). Instead, Curran calls for approaches that examine Shelley's shared "general tenor" and "textual strategies" with Dante ([43], p. 100). ${ }^{10}$ Yet in Curran's analysis, as well as in other preeminent commentaries, an assumed secularization narrative hazards limiting insight into what he calls Shelley's "remarkable internalization of the character of the Vita Nuova" ([43], p. 98) and what Timothy Webb describes as Shelley's "own secularized version of the Vita Nuova and the Divina Commedia" ([46], p. 187).

What can emerge from suspending the long-held assumptions of Romantic expressionism and secularization that go back to M.H. Abrams' The Mirror and the Lamp (1953) and Natural Supernaturalism (1971) respectively? This recalibration broadens the poem's problem from Emily's captivity to the emotional and intellectual opacity of the Florentine. It provides the opportunity to read Epipsychidion, like Prometheus Unbound, as a work in which a problematic yet sympathetic protagonist undergoes an important mental revolution that corrects an intellectual and emotional flaw. This not only resonates with the preface, which draws attention to the "singular" life of this "unfortunate friend" ([27], pp. 392, 393) and with Dante's Vita Nuova, but also harmonizes with Shelley's own frustration with biographical appropriations of the poem. In a reaction against early attempts to work out the relationships among its figures, Shelley announced his intention to "write a Symposium of my own to set all this right" ([47], p. II:363). The reference to Plato's Socratic dialogue is crucial, not because that classical philosophic work is upfront about the historical identities of its characters such as Agathon and Alcibiades [17], but rather because it suggests that an intellectual and ethical problem about love, which is at the heart of The Symposium, is also self-consciously at the heart of Epipsychidion. Shelley's Symposium would thus revisit the terms of the erotic argument in Epipsychidion that have been misconstrued. It also suggests a philosophic plot in which initially compelling viewpoints about love, such as the mythical monoecism of Aristophanes and the physiological affinities of Eryximachus, are later overthrown by a better conception, namely Diotima's erotic philosophical ascent [17]. In the horizon of expectations formed by Plato's Symposium and Dante's Vita Nuova, Shelley's labeling the poem an "idealized history of my own life and feelings" warrants consideration of what ideal version of love has transformed those biographical elements ([47], p. II:434).

Shelley's infusion of immediacy and potency to a philosophic debate through plotting with personal elements risked distracting scandalized readers, but this was also Dante's risk in Vita Nuova. It is perhaps irresistible to follow the centrifugal path from Dante's initial encounter with Beatrice in Vita Nuova to its theological culmination in the highest heavens of Paradiso, where Dante recalls "gazing into the beautiful eyes / which Love had made into the snare that caught me" and credits this love of Beatrice with the power to "imparadise" his mind ([48], 11. XXVIII.11, 12, 1). Yet Vita Nuova has a structural logic and integrity of its own and critically narrates the effect of the initial "moment I saw her" on the character of the young Dante figure, who trembles "violently" under the thrall of Cupid, "deus fortior me, qui veniens dominabitur mihi [a god more powerful than I who comes to rule over me]" ([49], ch. II. 12, 14, 16, 17). ${ }^{11}$ The enamored protagonist is, however, initially more monstrous than glorified, and certainly not yet imparadised. He falsely and exploitatively courts other young women as a "simulation," a "screen love" to hide his feelings for Beatrice from the public in his complex, often angry, loving quest that is part desperation and part vituperation (chs. V, IX). He tabulates her standing in his actuarial ranking of the sixty most beautiful women in the city (ch. VI). His fantasizing subjects him to a paralyzing physical lethargy (ch. XI.15-17), which can only be punctured by a perceived slight from an understandably indignant Beatrice (chs. X-XII). This drives him into solipsistic weeping, "like a little child that has been beaten" (ch. XII.8, 9). He becomes as

10 To that end, Weinberg provides a more detailed account of Viviani's biography in relation to the Dantean corpus, and Pite's study of Dante and the Romantics which focuses almost exclusively on Shelley's last poem, "The Triumph of Life," underscores that "Shelley knew Dante's works better than any of the other Romantic poets did" ([44], pp. 135-63; [45], p. 163).

11 Subsequent citations of Vita Nuova will be given parenthetically with chapter number and, where relevant, line number. 
confused and potentially self-destructive as in the "dark wood" of Inferno ([50], 1. I.2). Nevertheless, this youth labors under the false confidence that he knows, at this stage, the nature of love and is the true and faithful servant of the god Eros (ch. II).

The poet and the poem itself, however, contradict this claimed understanding of love from the very outset. The first significant encounter with Beatrice leads the younger Dante back to the "loneliness" of his "room" (ch. III.14). The ensuing dream, in which Eros force-feeds the poet's ardent heart to a naked, semi-conscious Beatrice, becomes the topic of Vita Nuova's first sonnet:

Joyful Love seemed to me and in his keeping

He held my heart; and in his arms there lay

My lady in a mantle wrapped, and sleeping.

Then he awoke her and, her fear not heeding,

My burning heart fed to her reverently.

Then he departed from my vision, weeping. (ch. III)

This circulated sonnet may have endeared Dante to Guy Cavalcanti and inscribed him within what Curran has called "a coterie of poets who inspire one another with...their devotion to chivalric love" ([43], pp. 95-96), but within the sonnet itself the god, who is Love, weeps. The cause of these tears remains unexplained in the critique or confusion concluding the otherwise swooning sonnet. Yet that weeping should cause the reader to look back, just as the older Dante looks back at his younger self, and to reflect on the order of his love. In the self-contained and self-serving fantasy, Beatrice is only an abject, unwilling supplier of the poet's emotional intensity and a platform for launching his alternating sense of delicious agony or transcendent bliss. It turns the love relationship into, at best, an act of consumerism or, at worst, a fantastical form of divinely sanctioned sexual assault.

It is just such an exploitative, ultimately solipsistic form of love that Benedict XVI laments in Deus Caritas Est. According to his critique, such "ascending love" precipitates a break in the relationship with God, substituting instead a "kind of intoxication" that is a form of Platonic "divine madness" which seductively "tears man away from his finite existence and enables him, in the very process of being overwhelmed by divine power, to experience supreme happiness" ([35], no. 4). In this account, this feeling of ecstasy, however, is never really $e k$-stasis, a stepping out of the self to encounter the divine Other, but rather an internalized euphoria. The argument is not just theological, however. Deus Caritas Est is equally concerned about the disjunction that this "counterfeit divinization of eros" produces at the interpersonal level between lover and beloved. With a comparison to Greek religious practices requiring temple prostitutes to provide "divine intoxication," Benedict XVI critiques the instrumentalization of the beloved in which commodified women were "not treated as human beings and persons, but simply used as a means of arousing 'divine madness': far from being goddesses, they were human persons being exploited" ([35], no. 4). In chapter XII of Vita Nuova, the god Eros-still weeping-returns to chasten and correct a similar exploitative and self-absorbed love in Dante, who cries over "simulacra nostra"-our false images. The young protagonist then finally engages in a philosophical and ethical encounter that leads him to ask why his acts have saddened the god. To this first real question of the book (why does Love weep?), the god replies: “Ego tanquam centrum circuli, cui simili modo se habent circumferentiae partes; tu autem non sic [I am like the centre of a circle, to which the parts of the circumference are related in similar manner; you, however, are not]" (ch. XII.14, 18-21). The god's geometric symbol of the proportioned circle does anticipate, in miniature, the ordered and complete cosmic orbits that sing through Paradiso. It also clearly and unmistakably excludes the wallowing young Dante from such balanced grandeur with the forceful, blunt rebuke: Tu autem non sic-you, however, are not so. The harsh message to the young Florentine is that he is an isolated, disconnected point, disordered and disruptive of Love's harmony.

"Tu autem non sic"- this is also the message delivered to Shelley's lyric narrator, the Florentine friend who likewise misconstrues the nature of love as self-serving divine intoxication. This narrator has constructed a stringent division of body and soul, whose Manichean dualism denigrates the 
physical and elevates the spiritual. The narrator's version of this bifurcation derived from Platonism is pronounced and extreme. Through it, Emily's essential, real humanity becomes her angelic heart that is "veiled" beneath her outward, bodily manifestation as a "Woman" (1. 22). This anthropological sense of vaunted spirit set against repressive corporeality governs the narrator's metaphysics as "light, and love, and immortality" strain against this "low and worldly shade" of earth (11. 24, 16). Emily stands at the center of a cosmic dichotomy of good and evil, spirit and flesh, living fire and dead cold: "Sweet Benediction in the eternal Curse! /Veiled Glory of this lampless Universe!" (1l. 25, 26). The inescapable, dead, dark, icy world stains even the poetry itself, marring its "song" with not only "mortality" but "much mortality and wrong" (1l. 35, 36). These latter terms are tautological in this philosophical framework, in which to be mortal is to be wrong. In this opening section, the real antagonist is the "worm beneath the sod" that corrupts and consumes the rotten flesh in a way that seems to threaten, or at least disturb, the living spirit (1. 128).

The poem makes the problematic nature of this worldview evident in two ways: the first referencing Emily and the second, the Florentine narrator. The narrator's metaphysical approach to Emily's confinement demonstrates a self-contradictory political and philosophic blindness that Shelley's poetic diction prods. The Florentine initially separates Emily's soul—her "High, spirit-winged Heart"-from her flesh and circumstances (1. 13). Yet while thus apostrophizing the soul's soaring powers, he laments that Emily's imprisonment has buried her "beneath" this world's restricting bounds (1. 22). Yet, in its continued address to her, the poetry contradicts any sense of enclosure and confinement: "Thou Moon beyond the clouds! Thou living Form/Among the Dead! Thou Star above the Storm!" (11. 27, 28). If Emily is truly "beyond" and "above" and stands out as arisen among the walking "Dead," then her convent is not really a jail at all. Emily would be like the condemned Socrates in his Athenian prison as portrayed by Plato in the dialogue Crito. There, Socrates asserts his freedom within the prison walls since no injustice can harm or confine a just and good man. If Crito is wrong to offer the mentally emancipated Socrates escape, so too does Emily already transcend liberation. The Florentine narrator is thus wrong to cry for her: "I weep vain tears: blood would less bitter be, /Yet poured forth gladlier, could it profit thee" (1l. 19, 20). He corresponds to Shelley's other vain weepers, like those in Adonais, whose grief is corrected through a metaphysical re-education.

This weeping, however, reveals the more serious problem of the Florentine narrator's egocentricity. This weeping is like the solipsistic and inward-looking weeping of the young Dante alone in his room. It shows that the self-involved narrator is not really regarding Emily, but rather using the image of her as a "Sweet Spirit" for his own metaphysical revelry. The culmination of his philosophical narcissism is the type of imagined "divine intoxication" described by Benedict XVI. It takes less than one-hundred lines for this poem, which is addressed to Emily, to switch from its litany of apostrophes ("Sweet Spirit," "Seraph of Heaven," "Sweet Lamp") into third-person description ("She met me...") (11. 1, 21, 53, 72). This rupture in form underscores a psychic shift in the Florentine friend from what the philosopher Martin Buber terms a relational and mutual I-Thou encounter to a quantifying and instrumentalizing I-It assessment [51]. This syntactical breach, which makes Emily available as an object, enables the narrator to launch his rapturous Platonic ascent from her. Shelley borrows the courtly poetic language of the blazon, which catalogues the parts of an admired woman's body. He does so with a difference, however, as the gazing Florentine connects each corporal item with a new stage of transcendent inebriation:

The Brightness

Of her divinest presence trembles through

Her limbs, as underneath a cloud of dew

Embodied in the windless Heaven of June

Amid the splendour-winged stars, the Moon

Burns, inextinguishably beautiful:

And from her lips, as from a hyacinth full

Of honey-dew, a liquid murmur drops, 
Killing the sense with passion; sweet as stops

Of planetary music heard in trance. (11. 77-86)

Unlike a typical blazon that can get bogged down in repetitive inventories of fingers and foreheads or get caught up in voyeuristic, sexual delectation, the airy and ecstatic — but still solipsistic - effects on the gazer overwhelm the cursory mention of "Her limbs" and "her lips." He mounts upon Emily for an "ascent of being" similar to that undertaken by the Unitarian elect in Coleridge's 1795 Religious Musings, the work of another young, Radical Platonist:

And gazing, trembling, patiently ascend

Treading beneath their feet all visible things

As steps, that upward to their Father's Throne

Lead gradual—else nor glorified nor lov'd. $([52], 11.50-53)^{12}$

Shelley's "gazing, trembling" narrator only glances at Emily's physical form, barely taking in her limbs and lips as "visible things." As in Coleridge's poem, the interest is solely in her soul, the spiritual essence beneath the barely mentioned body that is finally released from that dross. The blazon is broken, cut short to capture the "glory of her being" flying forth from the "dead, blank, cold air with a warm shade/Of unentangled intermixture" (11. 91-93). The image is abstract, mental, and difficult, but does suggest that its "unentangled" culmination is one in which the two elements-mind and material-have been split. The narrator has used Emily in order to gain access to a visionary thrall of purified spirit unencumbered by any earthly, fleshly clogs. She has enabled an imaginative ascent that "kills," in the dualistic terms of the poem, "the worm" (1l. 167, 168).

Like Coleridge's treaded "steps," however, it is unclear how Emily herself participates in the vision of cosmic unity that breaks out in Epipsychidion. In the onrushing, inebriating expansion of "Love, of light and motion" (1. 94), Emily's body returns only to be submerged:

One intense

Diffusion, one serene Omnipresence,

Whose flowing outlines mingle in their flowing,

Around her cheeks and utmost fingers glowing

With the unintermitted blood, which there

Quivers, (as in a fleece of snow-like air

The crimson pulse of living morning quiver,)

Continuously prolonged, and ending never,

Till they are lost, and in that Beauty furled

Which penetrates and clasps and fills the world;

Scarce visible from extreme loveliness. (11. 94-104)

The tone is one of abounding celebratory excess, but its insidious undertow should not be missed. The blazon returns-“"her cheeks and utmost fingers"—only to be indulgently drowned out by this flood of power and light. Her body has bolted back up into view-like Wordsworth's drowned man in The Prelude ([54], 11. V.470-73) —only for the narrator to delight in her submersion, "lost" and no longer "visible" in the glorious metaphysical flow. The passage lingers over Emily like a drowning Ophelia, not mourning a "muddy death" but rather celebrating a unification with "the glassy stream" ([55], 11. IV.vii.184, 168). The scope of this flowing vision, however, goes global, if not universal, as it "fills the world." In the process, nothing besides remains of Emily. Indeed, all seems lost in the indistinct deluge,

12 For an account of Coleridge's adaptation of the "ascent of being" from an English tradition of thought and verse going back to the Cambridge Platonists, see Jonathan Wordsworth [53]. 
except perhaps the Florentine who continues to gaze on this "sweet Death" in ecstatic rapture (1. 73). He alone is left to enjoy the gnostic apotheosis as part of his own, autonomous sense of divinization.

This movement to subsume the beloved Emily's individuality into a solipsistic unity, all in the name of serving love, has irked many critics. Ghislaine McDayter has summarized this line of critique: "Far from being a productive or natural (i.e., heterosexual) union, Shelley is either seen to 'cannibalize' his muse for his personal fulfillment, to 'colonize' her for his own poetic needs, or to ignore her altogether in an episode of narcissistic psychosis" ([56], p. 23). Nancy Moore Goslee sees the shift from the series of "transcendent addresses" into a third-person narrative as a key moment in the "depersoning or dispersoning" of Viviani ([25], p. 148). Building on the work of Tatsuo Tokoo on the poem's drafts, Goslee also shows that the inspiration for Epipsychidion was originally another woman and possibly a fictional one, which further complicates and "intensifies the process of making her less and less actual" ([57]; [25], p. 149). ${ }^{13}$ In addition to this consumption of Emily, the narrator's position of himself as a center of gravity also shows itself at the end of the "planet-tempest" sequence, when he beholds the allegorical beloved planets and cries out: "This world of love, this me" (1. 346). Likewise, any paradise to be regained with Emily, any "trees of Paradise" that will grow under Emily's sunlight, are botanically sourced from the narrator's mental operations, his "flowers of thought" (1. 384).

While the tendency has been to critique these passages as, in Curran's phrase, Shelley's "unbridled egocentricity" ([43], p. 96), other formal elements indicate that Shelley himself is interrogating, and eventually correcting, the narrator's world view. He allusively ties the Florentine's soul-searching Platonism to Wordsworth, who, by 1821, had passed from Shelley's admired forerunner to bête noire in what Jeffrey Cox has called the romantic "culture wars" ([60], p. 13). The Florentine begins his spiritual autobiography by recounting his visionary childhood, which itself is inspired by an otherworldly vision from beyond or before the "clear golden prime" of his "youth's dawn" (1. 192). Its opening, "There was a Being..." (1. 190), recalls the opening of Wordsworth's "Immortality Ode": "There was a time..." ([61], 1. 1). The passage then follows in the footsteps of the Lake District boy, racing throughout nature for glimpses of "exceeding glory" amid "the enchanted mountains" (11. 199, 194). Shelley's anaphoric re-creation of a breathless vision already lost- "And from the breezes.../And from the rain.../And from the singing.../ And from all sounds..." (11. 206-9)—echoes Wordsworth's anaphoric "Ands," 14 while retracing enthused but ultimately grieving recollections of boyhood pursuit of the "glory and the dream" ([61], 1. 58). Despite the Immortality Ode's lament of "Our birth" as "but a sleep and a forgetting" ([61], 1. 59), it is not reflexive to think of Wordsworth as a Platonist. For Shelley, however, the association ran deep. Byron's uncharacteristically Platonic outbursts in the third canto of Childe Harold's Pilgrimage resulted, he claimed, from being dosed with "Wordsworthian physic" by Shelley in Switzerland ([62], 11. III.72-75; [63], p. 194). This prescription was issued even after Mary declared Wordsworth's The Excursion the work of a "slave" ([64], p. 25: 14 September 1814), but before he himself pilloried the Lake poet in "Peter Bell the Third" (1819) as a man misguided by the fiery dreams in his head, a bigot blinded by his own elevated thoughts and the nonsense of what Keats called the "egotistical sublime" ([65], p. I:387).

Epipsychidion also makes a similar, if subtler, critique of a Platonic "egotistical sublime." The unflinchingly simplistic declaration of the moral disjunction between the transcendence of the soul and the wretched vanity of the body is so austere, so rigid, and so doctrinaire, that it invites circumspection:

Mind from its object differs most in this:

Evil from good; misery from happiness;

13 Also, see Péter for the "objectivization" and "reification" of Emily ([29], p. 124); Essick for the way "consecutive images of Emilia take on a momentum of their own...without explicit return to the 'she' who initiates the sequence" ([58], p. 166); and Evans for how the "ostensible subject of the poem is Emilia Viviani, but the content of the poem is Shelley's own life quest" ([59], p. 81).

14 See the Ode's echoing lines beginning with "And" in stanzas 2-4 ([56], 11. 11, 20, 24, 29, 32). 
The baser from the nobler; the impure

And frail, from what is clear and must endure. (11. 174-77)

In the discursive world of the 1819 Prometheus Unbound, such overstated rhetoric and aggressive, isolated pontificating indicate that a character is bound either for a fall, like Jupiter, or for a conversion of heart, like Prometheus. The Florentine's pattern of bifurcated thought itself appears at the end of the third act of Prometheus Unbound:

Nor yet exempt, though ruling them like slaves,

From chance and death and mutability,

The clogs of that which else might oversoar

The loftiest star of unascended Heaven

Pinnacled dim in the intense inane. (1l. III.iv.200-4)

This vision of the good, unlimited mind not yet freed by the evil, limiting clog of the body was the original ending of Shelley's great work, but that visionary poem moves beyond its strictures in the fourth act, which celebrates a paradise on earth, physically substantiated in the spreading conjugal joy of the reunited protagonists Prometheus and Asia. A cosmic revelry that radiates outwards from the localized retreat of the two lovers likewise lyrically unites body and soul, heaven and earth. The next section of this paper will argue that Epipsychidion undergoes a similar transformation, abandoning the Florentine's Manichean spite for embodied life to offer, through human love, what Benedict XVI would positively identify as an experience in which "body and soul are inseparably joined and human beings glimpse an apparently irresistible promise of happiness" and enjoy a "certain foretaste of the Divine" ([35], nos. 2, 3).

\section{4. "Our Home in Love": Eros Regained in Epipsychidion (Lines 407-574)}

Prometheus Unbound renounces a disembodied flight to "unascended" Heaven, turning to witness the transformative gifts that descend from the union of Prometheus and Asia. The seemingly irreconcilable division between the fiery, living soul of Heaven and the icy, dead dross of Earth is no longer lamented or celebrated, but overcome. In act IV, Spirits answer Hours; the attendant character Ione dialogues with Panthea-all participate in an irresistible formal revision that shifts from dramatic monologues into flowing antiphons. The poem does not seek to "overleap" the corporeal "clogs" of "chance, and death, and mutability," but rather mortal conditions are revisited and revised in the descending transfiguration (11. III.iv.201-4). The remarkable fourth act rehearses "human love" making "all it gazes on, Paradise" (1l. IV.127-28). The prison of this world is not vacated, but rather becomes the site to "build a new earth and sea/And a Heaven where yet Heaven could never be" (11. IV.164, 165). Even the personified earth and moon—not locked away in a senseless and lonely cosmos of "intense inane" - meet in what "The Earth" describes as an orgiastic "animation of delight" (1. IV.322). The celestial "Moon" cries back to her worldly lover in enamored reply:

Some Spirit is darted like a beam from thee

Which penetrates my frozen frame

And passes with the warmth of flame-

With love and odour and deep melody

Through me, through me!-(1l. IV.327-31)

This passage breaks through the dichotomy of images of ice and fire that surround Emily and dissolves distance and division between the two categories of "good" mind and "evil" material. Unlike the dissolution of Emily into a radiant abyss, these two figures celebrate a marriage that leaves the identity of each in place. It is an enthralling moment, but one that does not soar into inebriated solipsism or drown the beloved in exploitative ecstasy, what Benedict characterizes as "mere fusion" or "a sinking" 
into a "nameless ocean" ([35], no. 10). Instead, the unity of the two lovers, Prometheus and Asia, has re-tuned the whole given universe to the note of reciprocal and reciprocating joy.

Without the clear heuristic marker of an act division or formal shift, Epipsychidion enters the same world charged by the grandeur of Eros in lines 407-574. If, as Curran suggests, the "planet-tempest" passage is among Shelley's most over-read and the "free love" section the most misleadingly excerpted, these lines may be among the most underappreciated and neglected of Shelley's passages. A shift in tone-from frantic speculation to calm petition-accompanies an even more drastic metaphysical shift that graciously unites what the dualism of Radical Platonism had consistently strove to put asunder. The trajectory is not Promethean, not to "oversoar" (1. III.iv.202). Instead, the humbler question— "wilt thou sail with me?"- - sets the tone. Its vector is horizontal; its pitch restrained. It is a question, spoken with immediacy and intimacy, unlike the force-fed passion that made Eros weep in Vita Nuova. The Florentine's offer is "oblative" and "descending" according to Benedict XVI's framework, and abandons his aspirant escape "above" and "beyond." The proposal is companionable and collaborative, addressed to a restored "Thou" in Buber's terminology. The reader can almost see the Florentine gesture towards Emily's spot in the boat, a welcome relief from her previous fall overboard into sheer luminosity. Unlike the strange path to the Florentine's mental Eden, this vessel has a specific destination, the domestic space on his "isle and house," which glow "under Ionian skies" (1l. 513, 422). It is not a suffering way station en route to "unascended Heaven," but rather a tranquil locale decorously cradled "'twixt Heaven, Air, Earth, and Sea" (1. 457). The house and island may be remnants of a golden age, but it remains "a favoured place" (1. 461). The descriptive exploration recaptures the anaphoric excitement of the young Wordsworth and Shelley as its light "floats like mist,"

And falls upon the eye-lids like faint sleep;

And from the moss violets and jonquils peep,

And dart their arrowy odour through the brain... (11. 448-51)

The sensual poesy, however, does not set up an imprisonment or consolation, but rather a discovery and a consummation, like the darting embrace of Moon and Earth in act IV of Prometheus Unbound. There is no fret over mortality or physicality in his extended invitation: "Be this our home in life" (1. 536). There is a new peace in that phrase "in life," a new peace with life that seems to offer through embodied human love, in Benedict XVI's words, an "irresistible promise of happiness." The calm proposal holds open a possible Paradise, a new life on Earth, girded by the "blue ÆEgean" in a home formed "ere crime/Had been invented, in the world's young prime" (11. 430, 488-89). The Florentine has certainly changed his song, his self, and his sense of the world, but this raises the questions of how, why, and when any such change of heart occurred.

I would locate the conversion, which is crucial to the poem's structure, between the opening section of Radical Platonic escape and the following section of conjugal invitation, in the syntactical gap of line 407: "The soul in dust and chaos. I I Emily," (caesura added, 1. 407). That such an important turning point could be compacted within a half-line may defy expectations, but such a momentous mental pivot has precedent in act one of Prometheus Unbound. The perpetually punished Prometheus, "eyeless in hate" (1. I.9), curses his unjust prosecutor and imagines trampling Jupiter in disdain, until he pauses: "Disdain? I I Ah no! I pity thee" (caesura added, l. I.53). All of the action of Prometheus Unbound-Asia's amatory migration, Prometheus's liberation, the lifting of the Earth's curse, Demogorgon's revolutionary sweep of Jupiter from an empty throne, the lover's retreat, the cosmic festival-all of this depends upon the movement of Prometheus's mind from vengeful disdain to forgiving pity. That shift remains hidden between the question mark and the exclamation of "Ah." The reader can speculate on how and why it occurs-perhaps Prometheus was prompted by the sound of his own venomous curses or by the imagined visage of lost, unjust Jupiter-but nevertheless this definitive and lasting conversion remains sudden and secreted in the mind of Prometheus.

Why and how does the Florentine in Epipsychidion change? Perhaps he has seen the inadequacy of the severed freedom offered in the last line's picture of a liberated "soul" whose body remains "in dust 
and chaos" (1. 407). A better explanation, however, would seem to be that his imaginative liberation of Emily has recalled her image, her very face. In looking into her eyes again, he finds it impossible to continue with his metaphysical gymnastics. Rather he must respond to her again as a person, as the living, breathing beloved. "Emily" - the vocative half line has returned to first-person direct address, a decisive and continued "thou," after a long bout of ascending third-person description. This return to "thou," to a caring and responsible word to and for Emily, embodies the mental re-orientation of the Florentine. Such a shift is akin to Dante's reordered address to Beatrice with a "new and nobler theme" in the dolce still novo, the sweet new style (ch. XVII). ${ }^{15}$ Dante's re-ordered praise does not look to possess or consume, pleases Eros for its lyric gratitude and joyous good-keeping, and survives loss and mortality.

The Florentine's mental shift from an ascending, antagonistic dualism to a gracious and responsive hylomorphism leads to a communal celebration of Eros that is more localized and realistic than act IV of Prometheus Unbound. The Ægean house is ethereal, but it also domestically plausible. The Florentine tells Emily that he has "sent books and music there" (1. 519), a quotidian inventory that recalls the inventoried "soft cell" in the chatty epistolary verse of Shelley's "Letter to Maria Gisborne" ([68], 11. 10, 54-105). He promises that in this civil seclusion Emily will be "lady of the solitude" (1. 514), a vow that her identity will remain as they move from the busy world into a home dedicated to love. She will not be subject to the overflowing egocentricity exhibited in the Florentine's previous visions that dissolved her into "one serene Omnipresence" (1. 95). Her bestowed title implies she will maintain her own presence and power. The two descend upon their common home and experience the type of climactic unity achieved between the Moon and Earth, but that is here grounded in the erotic union of two human lovers, fully present to each other in flesh and in spirit:

Our breath shall intermix, our bosoms bound,

And our veins beat together; and our lips

With other eloquence than words, eclipse

The soul that burns between them, and the wells

Which boil under our being's inmost cells,

The fountains of our deepest life, shall be

Confused in passion's golden purity,

As mountain-springs under the morning Sun.

We shall become the same, we shall be one

Spirit within two frames... (11. 565-74)

This coming together to "intermix" breath and feel "veins" that "beat together" reverses the earlier imagery of Emily's divisive transcendence represented as "unentangled intermixture" and "unintermitted blood" (11. 93, 98). In this moment of body and soul meeting, Shelley diverges from Plato and Dante, whose approaches to love culminate in philosophic contemplation of Being and a theological song of agape. Rather, Shelley finds wisdom and paradise in a transfigured vision of eros itself, of romantic love that sings anew the conjugal way of two becoming one. Yet in doing so, Epipsychidion need not be read as making a secular turn, but rather as gesturing toward the type of more sacramental project that Patmore in The Unknown Eros or Williams in Outlines of Romantic Theology would take up later. This Ægean interlude even anticipates Benedict's call for a theology of eros that respects human nature as a "unity in duality, a reality in which spirit and matter compenetrate, and in which each is brought to a new nobility" ([35], no. 5). This passage of serene Mediterranean domesticity seems to anticipate the encyclical's sense of an ordered eros informed by the divine that preserves "concern and care for the other," that seeks "the good of the beloved," and that renounces an ascending love of "self-seeking, a sinking in the intoxication of happiness" ([35], no. 6).

15 For a discussion of this transition, see Reynolds ([66] pp. xxi-xxiii). For Dante's own description, see Purgatorio ([67], 11. XXIV, 49-57). 


\section{5. “Wherefore Two?": The Aporia of Epipsychidion (Lines 574-604)}

Within the poem's structure, the vision of an animating eros dwelling within an ordered oikos only seems to be climactic. The poem began with a protagonist misguided by Manichean metaphysics that "cannibalized" the beloved. It portrayed this Florentine transformed through a mental revolution that led him down from his endangering dualism to propose a shared love that realizes a unity in duality. Yet, just like the vacated prison, this enthralling moment, when two become one flesh, is a false ending. Epipsychidion has one further frantic section (11. 574-91) before a Dantean envoi (11. 592-604). Following D.J. Hughes's seminal article [69], critics have characterized this last movement as one of "collapse" and assigned causes varying from Shelley's poststructural engagement with the instability of language ([59], pp. 82-83; [29], pp. 124-25; [39], pp. 138-39) to his embrace of the castration complex [56]. I do not propose to resolve or displace these diagnoses, but do wish to reexamine the imagery and outcome of this section in light of the poem's structural approach to eros and the Florentine's philosophical and emotional development. The unraveling of the poem stems from his inability to rest in the Ionian relationship. That restlessness seems to derive from an inability to understand and accept the love he has found with Emily. Whatever the intensity or meaningfulness of his relational experience, he cannot, without a new metaphysical understanding of it, inhabit this new life. He is thus driven back into his old mode of dualistic dreaming. As a result, this last section of Epipsychidion may not be best characterized as a collapse so much as a returning ascent, a relapse into inebriated ecstasy that loses the other in onanistic ontology.

For the Florentine, who lacks an intellectual rationale for the goodness of the "unity in duality," the draw of narcissistic ascent is too compelling, too ingrained, and too habitual. As a result, the lovers" "compenetrating" union of body and soul, which had reclaimed the body from renunciation and Emily from drowning, dust, and chaos, can only be seen as second best, a banal consolation. This decisive logic is once again compacted within the syntactical gap between sections. Just as the poet's description of his encounter with Emily gains a common rhythm that begins to "beat together," just as their bodies and souls "intermix" and become "confused," just as the passage's energy mounts to a height with the exclamation "oh!", just then the Florentine asks a sudden question:

We shall become the same, we shall be one

Spirit within two frames, oh! Wherefore two?

One passion in twin-hearts... (11. 573-75)

It is an embarrassingly odd moment to begin an inquiry into philosophic anthropology. Nevertheless, the question-“'Wherefore two?"- -steals the focus of the poem even though it receives no answer. In the Florentine's mind, no justification for their two-ness, for the good of their remaining two in this moment of unity, can be found. The poem moves on without a response. Emily is lost sight of, almost entirely and almost immediately, abstracted into spherical imagery more mental than that of the finale of Prometheus Unbound. Yet the Florentine goes further, following a dynamic that can "point to Heaven" (1. 583). His thought ascends again, in rapturous, repetitive language, into a new antagonistic dialectic in which "two" and "one" contest:

One hope within two wills, one will beneath

Two overshadowing minds, one life, one death,

One Heaven, one Hell, one immortality,

And one annihilation. (11. 584-87)

"Two" loses; "One" wins. After the second line, duality is gone, just as earlier the "flowing" light had slowly, but surely, enveloped Emily. Her loss in this passage, her sinking into a nameless ocean, is just as complete. The anaphora has grown more intense, leading not just lines, but gasping phrases-a repetitive pounding of "one" six times to replace the shared heart beat with Emily. To remove any doubt and any last trace of duality, the last phrase- "one annihilation" - posits a total erasure of 
Emily's identity ad nihil—into nothingness. Yet it is not all nothingness. The gazing Florentine remains, and his "soul" is intent on another ascent into "the height of love's rare Universe" (1. 589). Yet just as he previously lost Emily within the rapturous vision culminating in a "world of love, this me" (1. 346), so too does this passage end with the narcissistic swirl of an "I" without a "Thou": "I pant, I sink, I tremble, I expire!" (1. 591).

"Wherefore two?" The inability to think this mystery-how two "shall be one flesh" while still maintaining their own integrity (Mark 10:8)—leads to the beloved's oblivion and a spiral into the self. Whether this capitulation to an overwhelming unity should be attributed to Shelley or the Florentine is difficult to say. Shelley's consolation to Keats's mourners in Adonais (1821) is that the young poet has been "made one with Nature" ([70], 1. 42.370). But that elegy's metaphysics are more complicated than the Florentine's, for even as "the One remains" still "is heard" Keats's "voice in all her music" ([70], 11. 52.460, 42.371, 372). Rather, the failure of the Florentine protagonist to resolve the problem of love mirrors the conclusion of the source texts for Epipsychidion. While the character of Dante will eventually reunite in Paradise with Beatrice at the end of Purgatorio, he is love struck with the donna gentile (chs. XXXV-XXXVIII) at the end of Vita Nuova, a relationship whose meaning is as ambiguous as its merit. Likewise, at the end of Symposium, the insistently carnal Alcibiades has not received the message about philosophic, transcendent love that Socrates has conveyed from Diotima [17]. So, it would be generically fitting for Shelley to end Epipsychidion with a Socratic aporia-an acknowledged lack of knowledge. At a philosophical level, this would suggest that, with the character of the Florentine, Shelley has undertaken an erotic phenomenology that leads away from dualism and self-divination and leads him to a hylomorphic vision of body compenetrated by soul, of a relationship felt as duality in unity and defined by reciprocity and communion. However, the unanswered question of the Florentine-“"wherefore two?"-leads to the dissolution of that vision and comes to the limit of Shelley's exploration.

Nevertheless, even in its limned quest, Epipsychidion offers an opportunity for reflection on humane eroticism that may be considered postsecular in two ways. First, with regards to how we read late Shelley, it can broaden our sense of the capaciousness of his theological imagination. His rejection of Radical Platonism's dualism and his search for an ethical form of eros leads him to a "unity in duality" that approaches the Christian understanding of human love as outlined in Deus Caritas Est. In Shelleyan Eros (1990), William Ulmer was reasonably cautious in curbing his reading of Epipsychidion within the framework of a Shelleyan "rejection of Dantean theocentrism" ([39], p. 136). Yet suspending that assumption of the secularization thesis, at least in the case of Epipsychidion, may also allow us to see the full extent of Shelley's ability to consider and explore a theological position in his phenomenology of eros, even though this poem ultimately leaves that position behind. Second, the way that the poem self-consciously depicts the Florentine's departure from a desirable reciprocal communion with the beloved makes it a work that philosophically ventures into territory which postsecularism attempts to describe. Although the Florentine cannot abide with the "unknown god" of Christian eros, his rejection of this mode of loving takes him back to an aggressive solipsism that the poem itself has already discredited. No clear alternative emerges, and Shelley refuses to orchestrate another vision of humanity, love, and god. The poem offers neither an affirmation of faith, nor an equally certain rejection of faith. Such "unsettled terrain," in which the nature of good human love can become a genuine question again, may not only help us interpret Epipsychidion but also invite both religious and unreligious thinkers to approach it anew dialogically. In his exchange with Habermas on the nature of secularization and the possibility of communication and collaboration in contemporary society, Ratzinger had noted the varying "closeness and the tension between these two poles" of belief and unbelief. He continued, "Sometimes they are willing to learn from each other, but sometimes they reject each other to a greater or lesser degree" ([21], p. 74). The philosophical horizon opened by Epipsychidion may thus exceed its dogmatic sermonizing on free love or its confessional turnings in the "planet-tempest passage" and involve Shelley in a broader dialogue with those trying to understand and respond to the "Love that moves the sun and all the other stars" ([48], 1. XXXIII.145). 
Conflicts of Interest: The author declares no conflict of interest.

\section{References}

1. Jonathan I. Israel. Radical Enlightenment. Oxford: Oxford University Press, 2001.

2. Percy Bysshe Shelley. "Prometheus Unbound." In Shelley's Poetry and Prose, 2nd ed. Edited by Donald H. Reiman and Neil Fraistat. New York: W.W. Norton, 2002, pp. 202-86.

3. Percy Bysshe Shelley. "The Necessity of Atheism." In The Prose Works of Percy Bysshe Shelley. Edited by E.B. Murray. Oxford: Clarendon, 1993, pp. 1-5.

4. Richard Holmes. Shelley: The Pursuit. New York: E.P. Dutton, 1975.

5. Stuart Curran. Shelley's Cenci: Scorpions Ringed with Fire. Princeton: Princeton University Press, 1970.

6. Jerrold E. Hogle. Shelley's Process: Radical Transference and the Development of His Major Works. New York: Oxford University Press, 1988.

7. Martin Priestman. Romantic Atheism: Poetry and Freethought, 1780-1830. Cambridge: Cambridge University Press, 1999.

8. Bertrand Russell. “The Importance of Shelley." In Fact and Fiction. New York: Routledge, 1994, pp. 11-16.

9. Colin Jager. Unquiet Things: Secularism in the Romantic Age. Philadelphia: University of Pennsylvania Press, 2015.

10. James Joyce. A Portrait of the Artist as a Young Man. Edited by Seamus Deane. New York: Penguin, 2003.

11. Clive Staples Lewis. "Shelley, Dryden, and Mr. Eliot." In English Romantic Poets: Modern Essays in Criticism, 2nd ed. Edited by Meyer Howard Abrams. London: Oxford University Press, 1975, pp. 324-44.

12. Louis Dupré. The Quest of the Absolute: Birth and Decline of European Romanticism. Notre Dame: University of Notre Dame Press, 2013.

13. Robert M. Ryan. The Romantic Reformation: Religious Politics in English Literature 1789-1824. Cambridge: Cambridge University Press, 1997.

14. Stuart Curran. Shelley's Annus Mirabilis: The Maturing of an Epic Vision. San Marino: Huntington Library, 1975.

15. Francis Thompson. "Shelley." In The Works of Francis Thompson. London: Burns, Oates, and Washbourne, 1913, vol. 3, pp. 1-37.

16. Percy Bysshe Shelley. “On Christianity.” In The Prose Works of Percy Bysshe Shelley. Edited by E.B. Murray. Oxford: Clarendon, 1993, pp. 246-71.

17. Plato. The Symposium of Plato. Edited by David K. O'Connor. Translated by Percy Bysshe Shelley. South Bend: St. Augustine's Press, 2002.

18. John Cowie Reid. The Mind and Art of Coventry Patmore. New York: Macmillan, 1957.

19. Coventry Patmore. “The Morality of 'Epipsychidion' [1868]." In Courage in Politics, and other Essays, 1885-1896. Edited by Frederick Page. Freeport: Books for Libraries Press, 1968, pp. 110-14.

20. Charles Williams. (1937) 2001. Descent into Hell. Grand Rapids: Eerdmans.

21. Jürgen Habermas, and Joseph Ratzinger. The Dialectics of Secularization: On Reason and Religion. Edited by Florian Schuller. Translated by Brian McNeil. San Francisco: Ignatius, 2006.

22. Abraham J. Heschel. Who is Man? Stanford: Stanford University Press, 1965.

23. William Blake, William Wordsworth, Percy Bysshe Shelley, John Keats, and Samuel Taylor Coleridge. Great Poets of the Romantic Age. Narrated by Michael Sheen. Redhill: Naxos Audiobooks, 2010.

24. Earl R. Wasserman. Shelley: A Critical Reading. Baltimore: Johns Hopkins Press, 1971.

25. Nancy Moore Goslee. Shelley's Visual Imagination. Cambridge: Cambridge University Press, 2011.

26. Hoxie Neale Fairchild. Religious Trends in English Poetry. New York: Columbia University Press, 1949, vol. 3.

27. Percy Bysshe Shelley. "Epipsychidion." In Shelley's Poetry and Prose, 2nd ed. Edited by Donald H. Reiman and Neil Fraistat. New York: W. W. Norton, 2002, pp. 390-407.

28. Kenneth Neill Cameron. "The Planet-Tempest Passage in Epipsychidion." Publications of the Modern Language Association of America 63 (1948): 950-72. [CrossRef]

29. Agnes Péter. "A Hermeneutical Reading of 'Epipsychidion'." Keats-Shelley Journal 42 (1993): 120-27.

30. Barbara Charlesworth Gelpi. "Keeping Faith with Desire: A Reading of Epipsychidion." In Evaluating Shelley. Edited by Timothy Clark and Jerrold E. Hogle. Edinburgh: Edinburgh University Press, 1996, pp. 180-96.

31. Diane Long Hoeveler. Romantic Androgyny: The Women Within. University Park: Pennsylvania State University Press, 1990. 
32. Michael O'Neill. Romanticism and the Self-Conscious Poem. Oxford: Oxford University Press, 1997.

33. Lori Branch. "Review of Religion, Literature and the Imagination: Sacred Worlds." Religion E Literature 47 (2015): 248-51.

34. Lori Branch. "Postsecular Studies." In The Routledge Companion to Literature and Religion. Edited by Mark Knight. Oxford: Routledge, 2016.

35. Benedict XVI. God is Love. Ijamsville: Librereia Editrice Vaticana, 2006, (in press, 2007).

36. Jean-Luc Marion. The Erotic Phenomenon. Translated by Stephen E. Lewis. Chicago: University of Chicago, 2008.

37. Jonathan I. Israel. Enlightenment Contested: Philosophy, Modernity, and the Emancipation of Man 1670-1752. Oxford: Oxford University Press, 2006.

38. James A. Notopoulos. The Platonism of Shelley: A Study of Platonism and the Poetic Mind. Durham: Duke University Press, 1949.

39. William A. Ulmer. Shelleyan Eros. Princeton: Princeton University Press, 1990.

40. Gary Kelly. The English Jacobin Novel 1780-1805. Oxford: Clarendon Press, 1976.

41. Percy Bysshe Shelley. "England in 1819." In Shelley's Poetry and Prose, 2nd ed. Edited by Donald H. Reiman and Neil Fraistat. New York: W.W. Norton, 2002, pp. 326-27.

42. Percy Bysshe Shelley. "Alastor." In Shelley's Poetry and Prose, 2nd ed. Edited by Donald H. Reiman and Neil Fraistat. New York: W.W. Norton, 2002, pp. 71-90.

43. Stuart Curran. "Epipsychidion, Dante, and the Renewable Life." In Dante and Italy in British Romanticism. Edited by Frederick Burwick and Paul Douglas. New York: Palgrave Macmillan, 2011, pp. 93-104.

44. Alan M. Weinberg. Shelley's Italian Experience. Basingstoke: Palgrave Macmillan, 1991.

45. Ralph Pite. The Circle of Our Vision: Dante's Presence in English Romantic Poetry. Oxford: Clarendon, 1994.

46. Timothy Webb. Shelley: A Voice not Understood. Atlantic Highlands: Humanities Press, 1977.

47. Percy Bysshe Shelley. Letters. Edited by Frederick L. Jones. Oxford: Clarendon, 1964.

48. Dante Aligheri. Paradiso. Translated by Robert Hollander and Jean Hollander. New York: Anchor, 2008.

49. Dante Alighieri. Vita Nuova. Translated by Barbara Reynolds. London: Penguin, 2004.

50. Dante Aligheri. Inferno. Translated by Robert Hollander and Jean Hollander. New York: Anchor, 2000.

51. Martin Buber. (1923) 2004. I and Thou. Translated by Ronald Gregory Smith. London: Continuum.

52. Samuel Taylor Coleridge. "Religious Musings." In Poetical Works. Edited by J. C. C. Mays. Princeton: Princeton University Press, 2001, vol. 1, pp. 171-91.

53. Jonathan Wordsworth. “The Infinite I AM': Coleridge and the Ascent of Being." In Coleridge's Imagination. Edited by Richard Gravil, Lucy Newlyn and Nicholas Roe. Cambridge: Cambridge University Press, 1985, pp. 22-52.

54. William Wordsworth. The Thirteen-Book Prelude. Edited by Mark L. Reed. Ithaca: Cornell University Press, 1991, vol. 1.

55. William Shakespeare. "Hamlet, Prince of Denmark." In The Complete Works of Shakespeare, 7th ed. Edited by David Bevington. Boston: Pearson, 2014, pp. 1091-49.

56. Ghislaine McDayter. "O'er Leaping the Bounds: The Sexing of the Creative Soul in Shelley's Epipsychidion." Keats-Shelley Journal 52 (2003): 21-49.

57. Tatsuo Takoo. “The Composition of 'Epipsychidion': Some Manuscript Evidence." Keats-Shelley Journal 42 (1993): 97-103.

58. Robert N. Essick. "'A shadow of some golden dream': Shelley's Language in Epipsychidion." Language and Literature 22 (1986): 165-75.

59. James C. Evans. "Masks of the Poet: A Study of Self-Confrontation in Shelley's Poetry." Keats-Shelley Journal 24 (1975): 70-88.

60. Jeffrey N. Cox. Poetry and Politics in the Cockney School: Keats, Shelley, Hunt and their Circle. Cambridge: Cambridge University Press, 1998.

61. William Wordsworth. “Ode." In Poems, in Two Volumes, and Other Poems. Edited by Jared Curtis. Ithaca: Cornell University Press, 1983, pp. 269-77.

62. Byron. "Child Harold's Pilgrimage." In The Complete Poetical Works. Edited by Jerome J. McGann. Oxford: Clarendon, 1980.

63. Ernest J. Lovell, Jr., ed. Medwin's Conversations of Lord Byron. Princeton: Princeton University Press, 1966. 
64. Mary Shelley. The Journals of Mary Shelley. Edited by Paula R. Feldman and Dana Scott-Kilvert. Oxford: Clarendon Press, 1987.

65. John Keats. The Letters of John Keats. Edited by Hyder Edward Rollins. Cambridge: Harvard University Press, 1958.

66. Barbara Reynolds. "Introduction." In Vita Nuova. By Dante Alighieri. London: Penguin, 2004, pp. xiii-xxix.

67. Dante Aligheri. Purgatorio. Translated by Jean Hollander and Robert Hollander. New York: Anchor, 2003.

68. Percy Bysshe Shelley. "Letter to Maria Gisborne." In Shelley's Poetry and Prose, 2nd ed. Edited by Donald H. Reiman and Neil Fraistat. New York: W.W. Norton, 2002, pp. 328-37.

69. Daniel J. Hughes. "Coherence and Collapse in Shelley, with Particular Reference to Epipsychidion." ELH 28 (1961): 260-83. [CrossRef]

70. Percy Bysshe Shelley. "Adonais." In Shelley's Poetry and Prose, 2nd ed. Edited by Donald H. Reiman and Neil Fraistat. New York: W.W. Norton, 2002, pp. 407-27.

(C) 2016 by the author; licensee MDPI, Basel, Switzerland. This article is an open access article distributed under the terms and conditions of the Creative Commons Attribution (CC-BY) license (http://creativecommons.org/licenses/by/4.0/). 